\title{
Mortality in relation to season, age, sex, and reproduction in Columbian ground squirrels (Spermophilus columbianus)
}

\author{
P. Neuhaus and N. Pelletier
}

\begin{abstract}
We investigated the timing of and age at mortality in Columbian ground squirrels (Spermophilus columbianus) in relation to sex and reproductive status. Life-history data were collected from 1994 to 1999 in the foothills of the Rocky Mountains, Alberta, Canada. We predicted increased mortality for males during mating and for females during lactation. Further, we expected reproductively successful females to have higher mortality than females that did not reproduce successfully. Finally we assumed that at some age reproductive success of females would decrease and mortality increase because of old age. For both sexes, survival over winter was high (ca. 90\%) for adults. While there was a significant increase in mortality of adult males during the mating season, females did not have higher mortality during lactation than during the rest of the active season. Reproductive status influenced mortality in females: non-reproducing females had a higher chance of surviving than reproducing females. Females that weaned young were more likely to die after the weaning period than females that lost their litter during lactation. There was a positive correlation between maternal survival and survival of offspring to yearling age. Our results showed evidence of trade-offs between reproduction and survival of male and female Columbian ground squirrels.
\end{abstract}

Résumé : Nous avons étudié la phénologie de la mortalité et déterminé l'âge au décès chez le Spermophile du Columbia (Spermophilus columbianus) en fonction du sexe et du statut reproducteur à partir de données démographiques recueillies de 1994 à 1999 sur les contreforts des Rocheuses en Alberta, Canada. Nous avons posé en hypothèse que la mortalité augmenterait chez les mâles au cours de la période des accouplements et chez les femelles durant l'allaitement et que les femelles qui réussiraient leur reproduction auraient une mortalité plus forte que les femelles qui la rateraient. Enfin, nous nous attendions à un déclin de la reproduction chez les femelles à partir d'un certain âge et à une augmentation de la mortalité due à la vieillesse. Chez les adultes mâles et femelles, la survie en hiver est élevée (ca. $90 \%$ ). Il se produit une augmentation significative de la mortalité des mâles pendant la saison des accouplements, mais les femelles n'ont pas un taux de mortalité plus élevé durant l'allaitement que pendant le reste de la saison d'activité. Le statut reproducteur influence la mortalité chez les femelles : en effet, les femelles non reproductrices ont de meilleures chances de survie que les femelles reproductrices. La probabilité de mourir est plus forte chez les femelles qui gardent leurs petits jusqu'au sevrage que chez celles qui perdent leur portée pendant l'allaitement. Il y a une corrélation positive entre la survie des femelles et la survie des jeunes au cours de la première année. Nos résultats indiquent qu'il s'établit des compromis entre la reproduction et la survie chez les mâles et les femelles du Spermophile du Columbia.

[Traduit par la Rédaction]

\section{Introduction}

Causes of mortality in mammals are manifold. While a high percentage of individuals die as subadults, never reaching reproductive maturity, reasons for mortality of adults can be diverse. In many species, a high number of animals die because of predation, but starvation due to unfavorable envi-

Received August 4, 2000. Accepted November 27, 2000.

Published on the NRC Research Press Web site on March 5, 2001.

P. Neuhaus. ${ }^{1}$ University of Cambridge, Large Animal Research Group, Department of Zoology, University of Cambridge, Downing Street, Cambridge CB2 3EJ, United Kingdom.

N. Pelletier. Départment de biologie, Université de Sherbrooke; Sherbrooke, QC J1L 2R1, Canada.

${ }^{1}$ Corresponding author (e-mail: peter_neuhaus@hotmail.com). ronmental conditions or due to investment in reproduction and old age might be other important factors.

In Columbian ground squirrels (Spermophilus columbianus), a hibernating rodent, mortality in the first year is higher than in older individuals (Boag and Murie 1981; Zammuto 1987), and it is higher in males than in females in all age-classes (Boag and Murie 1981; Festa-Bianchet and King 1984). These differences are not only due to the male-biased dispersal (Boag and Murie 1981; Festa-Bianchet and King 1984) but might also reflect high reproductive costs during the mating season (Neuhaus et al. 1999). In Richardson's ground squirrels (Spermophilus richardsonii), adult mortality was higher in males than in females during the mating season, active season, and the whole year (Michener and Locklear 1990; Michener 1998). Trade-offs between predation risk and foraging have been shown to exist in Belding's ground squirrels (Spermophilus beldingi), where well-fed animals showed more vigilance than deprived individuals (Bachman 1993). Lactating female hoary marmots (Marmota caligata) and 
Columbian ground squirrels fed farther from escape burrows and showed less vigilance than nonlactating females, presumably because of higher energy needs (Barash 1980; MacWhirter 1991). This likely leads to higher mortality through predation as well as the lower survival rate resulting from an inferior body condition. Hence, even when predation is the proximate cause of mortality, energy requirements might be the ultimate influence because animals that require more food may take extra risks.

In Richardson's ground squirrels, males gain access to estrous females by chasing and fighting with other males, leading to mass loss during the mating season, which explains the high male mortality during this period (Michener 1984, 1998; Michener and McLean 1996). A similar pattern is evident in Columbian ground squirrels, where males do not gain mass during the mating season whereas females do gain mass (Murie and Harris 1978; Boag and Murie 1981). If weather conditions are unfavorable during the energetically demanding mating season, mortality increases in both sexes with a higher increase in males than in females (Neuhaus et al. 1999). Other environmental influences such as weather patterns, snow cover, or snowmelt also have a profound influence on life history (Dobson and Murie 1987). Food resources have a large influence on litter size, juvenile survival, and body mass (Dobson and Kjelgaard 1985).

As shown for Richardson's ground squirrels, energy requirements differ greatly between males and females; males have their greatest energy demands during mating. Females on the other hand invest most energy directly into their offspring during gestation and lactation (Michener 1998). In various mammals, lactation is the most costly part of female reproduction (König et al. 1988; Clutton-Brock et al. 1989; Atramenotowicz 1992). While animals are expected to optimize their lifetime reproductive success, the energy expended during reproduction likely leads to an increased risk of mortality (Saino et al. 1999) due to predation and depletion of fat reserves. Whereas younger animals might appear to take future reproduction into account, older animals are likely to suffer greater risks to ensure that their current offsprings have a good chance to survive and reproduce (Williams 1966; Stearns 1976). These assumptions lead to tradeoffs associated with parent-offspring conflict in younger animals (Williams 1966; Trivers 1974).

In Columbian ground squirrels, no reproductive costs have been shown so far for males, and some studies yielded no evidence of reproductive costs in females (Murie and Dobson 1987; Hare and Murie 1992). More recent studies, however, have documented such costs (Neuhaus 2000a, 2000b). Impact of feeding behavior (Ritchie 1990), food quantity (Dobson and Kjelgaard 1985), weather patterns and year effects (Dobson and Murie 1987; Neuhaus et al. 1999), or body condition (Murie and Boag 1984) have been shown to have a profound influence on life history and survival in Columbian ground squirrels. However little is known about when during the yearly cycle animals die. In this paper our goal was to look at the timing of mortality in relation to reproduction and hibernation, comparing different age and sex classes.

Because it is rare to observe directly the cause of mortality in wild animals, we inferred causes of mortality by looking at age, sex, and reproductive status of individuals at the date of disappearance from a ground squirrel colony in southwestern Alberta. Because of sexual differences in timing of reproductive investment, we predicted that mortality would be highest during and shortly after the mating season for males and during lactation for females. Furthermore, we predicted mortality would be higher for reproductively successful females than for unsuccessful females during the postweaning and hibernation periods. Such mortality might be associated with poor body condition due to high investment in reproduction or with delayed preparation for hibernation in reproductively successful females. Because younger females reflect selection favoring their reproductive success, we expected that reproductive success would increase with age, concurrent with increase in mortality caused by increased reproductive costs. As age increases above some threshold, we predicted that animals would show an increase in mortality and a drop in reproductive success due to senescence (Promislow 1991)

\section{Methods}

A colony of Columbian ground squirrels was studied in the Sheep River Wildlife Sanctuary, Alberta, Canada $\left(110^{\circ} \mathrm{W}, 50^{\circ} \mathrm{N}\right)$, from April 1994 to May 1999. Between 120 and 250 ground squirrels (excluding juveniles) inhabited the subalpine meadow of ca. 2.5 ha at an elevation of ca. $1500 \mathrm{~m}$. The colony was established in 1984 (Wiggett and Boag 1986) and studied since then, except in 1991 (Stevens 1997), so the age of all squirrels present in the colony was known. Columbian ground squirrels have a short active season of less than 4 months followed by more than 8 months of hibernation (Dobson et al. 1992). In all years research started at the beginning of April and ended near the end of August after all individuals started hibernation. Males are the first to emerge from hibernation in spring followed by females, while sexually inactive animals are the last to emerge (Murie and Harris 1982). Females mate within 4 days after emergence from hibernation (Murie and Harris 1982; Murie 1995). Twenty-four days after mating, females give birth in a burrow to 1-7 young (yearly means in our study were between 3 and 4); 27 days after birth the young emerge above ground for the first time and start to feed on vegetation (Murie and Harris 1982). Females cease lactation soon after and prepare for hibernation by molting and accumulating fat reserves (Neuhaus 2000b).

All individuals in the colony were marked with a numbered fingerling fish tag in each ear and with a unique mark painted with black hair dye (Clairol, No. 124 natural blue black, type 3 permanent) on their back for identification from a distance. All ground squirrels were trapped once weekly using National and Tomahawk live traps baited with peanut butter. When an animal was caught, its mass was taken and its reproductive status determined by examining for swelling of the vulva and nipples in females and pigmentation of the scrotum in males (Murie and Harris 1982). Trapping, together with regular scanning of the whole meadow (3-7 days a week) from wooden stands that were 2-3 m high, helped to establish the day of disappearance of individuals. Since dispersal from one colony to another of males older than 2 years and females older than 1 year is extremely rare (Festa-Bianchet and King 1984) and was never observed during this study, we assumed that adult animals that disappeared from the colony were dead. Disappearance of animals between the age of 1 and 2, however, does reflect a combination of mortality and dispersal.

Because we observed early hibernation during the second half of July, animals disappearing from the population after 16 July and not reemerging the following spring were considered to have died during hibernation. For males, we considered the day when the last 
Table 1. Percent survival of Columbian ground squirrels in relation to age and sex.

\begin{tabular}{lll}
\hline & \multicolumn{2}{l}{ Percent survival } \\
\cline { 2 - 3 } & Females & Males \\
\hline Young & $37.0(162)$ & $36.5(164)$ \\
Yearling & $63.7(91)$ & $39.6(101)$ \\
2 years old & $81.1(74)$ & $72.3(47)$ \\
3 years old & $77.1(83)$ & $74.5(47)$ \\
4 years old & $78.3(69)$ & $71.1(45)$ \\
5 years old & $72.4(58)$ & $53.6(28)$ \\
6 years old \\
7 years old & $79.5(39)$ & $56.5(23)$ \\
8 years old & $73.3(30)$ & \\
9 years old & $66.7(21)$ & \\
Total & $33.3(12)$ & \\
\hline
\end{tabular}

Note: Numbers in parentheses are sample sizes. Females were first reproductively active as 2-year-olds and males as 3 -year-olds.

${ }^{a}$ Males $\geq 6$ years old were pooled because of the small sample size

${ }^{b}$ Females $\geq 9$ years old were pooled because of the small sample size.

female mated as the end of the reproductive season. For females, we were able to establish their reproductive cycle individually by adding 24 days to the date of mating for gestation and another 27 days for lactation. The date of mating ( \pm 1 day) was known from observations and trapping during the mating season. Hence we were able to determine when females disappeared in relation to their reproductive status.

To compare female versus male mortality rates, we split the year into three parts. The first part was from emergence to 15 May, which incorporates emergence and mating, the second from 16 May to 9 July, which is part of gestation to the end of lactation in females, and the third from 10 July (when all juveniles had emerged) to the following spring, combining the postweaning and hibernation periods.

To analyze sexual differences in mortality we used $\chi^{2}$ tests. Because 2-year-old females mated (P. Neuhaus and N. Pelletier; unpublished observations), they were included in the analyses. Males were only included as $\geq 3$-year-olds, since they rarely mate as 2year-olds in this area. Mortality of females of different reproductive status (lactating or not, weaned young or not) was also compared using $\chi^{2}$ analyses. To test sexual differences in date of disappearance we used Mann-Whitney $U$ tests (SPSS statistical package; Norusis 1994). For analyzing differences in mortality between active seasons and hibernation we used a $G$ test, correcting for the length of each season in days (Sokal and Rohlf 1995). Since we wanted to look at when animals died, some surviving individuals were used in the statistics more than once over the course of the study. However, each individual was counted only once a year.

\section{Results}

There was no difference in the total numbers of male and female offspring (164 males, 162 females for 1994-1997 combined) or in survival of young to yearling age (60 males and 60 females). More males than females, however, disappeared (for yearlings this includes mortality and dispersal for both sexes) from yearling age to the next spring (Pearson's $\chi^{2}=11.16, P<0.001$; Table 1$)$. In total, 144 adult animals died in the 5 years of our study, while 385 (cumulative) adults survived to the following spring (73\% survival).
Table 2. Mortality in female and male Columbian ground squirrels during mating until 15 May, 16 May - 9 July, and 10 July to the next spring.

\begin{tabular}{|c|c|c|c|c|}
\hline & $\begin{array}{l}\text { Percent } \\
\text { survival }\end{array}$ & $n$ & $\begin{array}{l}\text { Pearson's } \\
\chi^{2}\end{array}$ & $P$ \\
\hline \multicolumn{5}{|l|}{ Mating } \\
\hline Males & 83.3 & 114 & 10.41 & $<0.001$ \\
\hline Females & 93.5 & 310 & & \\
\hline \multicolumn{5}{|c|}{ Gestation and lactation } \\
\hline Males & 84.8 & 112 & 0.07 & 0.8 \\
\hline Females & 85.8 & 338 & & \\
\hline \multicolumn{5}{|c|}{$\begin{array}{c}\text { Prehibernation and } \\
\text { hibernation }\end{array}$} \\
\hline Males & 88.8 & 107 & 0.7 & 0.4 \\
\hline Females & 91.5 & 317 & & \\
\hline \multicolumn{5}{|l|}{ Total } \\
\hline Males & 66.4 & 143 & 3.98 & $<0.05$ \\
\hline Females & 75.1 & 385 & & \\
\hline
\end{tabular}

In reproductively active animals (all females $\geq 2$ years old and all males $\geq 3$ years old), males were more likely to die than females (33.6 vs. $24.9 \%$; Pearson's $\chi^{2}=3.98, P<0.05$; Table 1). Mortality in females started to increase at 8 years of age and was significantly higher between older ( $>8$ years) and younger females (2-7 years; Pearson's $\chi^{2}=10.76, P<$ 0.001; Table 1). We observed no difference in reproductive success between older females and females 3-7 years old (45.5 and $45.9 \%$, respectively, weaned young; Pearson's $\chi^{2}=$ $0.002, P=0.96)$. Two-year-old females were less likely to wean young than older females $(21.6$ and $45.8 \%$, respectively; Pearson's $\left.\chi^{2}=14.47, P<0.001\right)$. The mortality of 2 year-old females, however, was not significantly different from the mortality of older females (18.9 and $26.3 \%$, respectively; Pearson's $\left.\chi^{2}=1.74, P=0.19\right)$.

In males, mortality started to increase at 5 years of age; 3 and 4-year-olds were more likely to survive than older males (Pearson's $\chi^{2}=4.73, P=0.03$; Table 1 ). The mean age of females was greater than that of males for all Columbian ground squirrels excluding juveniles, as well as for animals $\geq 3$ years old, after the age of dispersal (3.6 vs. 2.5 years, respectively, $U$ test, $Z=-7.02, P<0.001 ; 4.9$ vs. 4.3 years, respectively, $U$ test, $Z=-3.31, P<0.001$ ).

Male survival was much lower than female survival during mating but not during the subsequent two portions of the year (Table 2). Males that died during the active season disappeared, on average, on 26 May, whereas females disappeared on 7 June, which was significantly later ( $U$ test, $Z=$ $-2.7, P=0.007)$. There was also a significant difference between dates of disappearance for 2-year-old females, disappearing on average on 17 May, and older females, whereas 2-year-old females were not different from adult males (females, $U$ test, $Z=-2.77, P=0.006$; femalesmales, $U$ test, $Z=-0.45, P=0.66)$. Female and male survival were very high during hibernation compared with mating or prehibernation (females, $G$ test, $G_{a d j}=129.7, P<$ 0.001 ; males, $G$ test, $G_{a d j .}=99.66, P<0.001$; Table 3$)$. If survival during hibernation was excluded from analysis, there was still a significant difference in females and males 
Table 3. Mortality in Columbian ground squirrels in relation to their reproductive cycle.

\begin{tabular}{lclc}
\hline & \multicolumn{2}{l}{ No. of dead } \\
\cline { 4 - 4 } & $\begin{array}{l}\text { Duration } \\
\text { (days) }\end{array}$ & Observed & Expected $^{a}$ \\
\hline Females & & & \\
Emergence and gestation & 28 & 25 & 7.36 \\
Lactation & 27 & 29 & 7.10 \\
Post weaning & 43 & 15 & 11.31 \\
$\quad$ Hibernation & 267 & 27 & 73.15 \\
Males & & & \\
Emergence and mating & 35 & 19 & 4.61 \\
Prehibernation & 60 & 17 & 7.89 \\
Hibernation & 270 & 12 & 35.51 \\
\hline
\end{tabular}

${ }^{a}$ Values are based on duration of the period in days, assuming a constant daily mortality rate.

(females, $G$ test, $G_{a d j .}=10.5, P<0.01$; males, $G$ test, $G_{a d j .}=$ 6.3, $P<0.025)$.

In females $\geq 2$ years old, mortality between 10 June (at which time all females that conceived were lactating) and emergence the following year was significantly higher in lactating than in nonlactating females (Table 4). Females that weaned young were more likely to die than females that were lactating but did not wean young (Table 4). However, females weaning at least 1 young surviving to yearling age were more likely to survive than females weaning young that did not survive to yearling age (Table 4).

\section{Discussion}

The objective of this study was to examine the effects of age, sex, time of the year, and reproductive status on mortality in Columbian ground squirrels. Overall, males were more likely to die than females and mortality increased in males at a younger age than in females. We did not observe any bias in sex ratio at emergence of the young or in survival to yearling age. Low survival of young to yearling age has been shown previously in Columbian ground squirrels (Dobson and Murie 1987; Zammuto 1987). The much higher male disappearance between emergence from their first and second hibernation is likely due to the male-biased dispersal found in Columbian ground squirrels (Boag and Murie 1981; Festa-Bianchet and King 1984; Wiggett and Boag 1993) rather than to mortality per se. A tendency for males to die younger than females has been shown in Richardson's and Belding's ground squirrels and black-tailed prairie dogs (Cynomys ludovicianus) (Sherman and Morton 1984; Michener and Locklear 1990; Hoogland 1995). In our study, however, male Columbian ground squirrels after the age of dispersal do not have higher mortality than females up to the age of 4 (Table 1). Besides male-biased dispersal, another main factor leading to males being on average younger than females is that mortality in males increases at the age of 5 , whereas mortality of females does not increase until they are 8 years old.

In our study, mortality of adult ground squirrels was low during hibernation for both sexes, whereas it was relatively high in males during the mating season. This result is con- sistent with that in Richardson's ground squirrels, for which mortality during hibernation was low and similar in both sexes (Michener and Locklear 1990). We did not, however, find increased mortality in females during lactation compared with mating and gestation as we predicted. This might be because during lactation the nutritional content of the vegetation in our study area was usually highest (Bennett 1997), day length was longer, and temperatures were mild. Hence, the animals can compensate for the energetic costs arising from lactation.

Another reason for high survival of lactating females might be abortion or abandonment of the litter when costs are too high, thereby trading off current reproduction for future reproduction (Neuhaus et al. 1999). Lower female mortality during post weaning than during lactation or mating and gestation could be due to decreased energetic costs once lactation ceases or to decreased predation pressure because of increased dilution (more available prey) once young emerge above ground. Average date of female disappearance was later during the active season than for males, likely because of increased male mortality during mating. The earlier disappearance of 2-year-old females versus older females is more difficult to interpret. Perhaps this reflects low reproductive effort by 2-year-old females, resulting in low reproductive success. Further, low reproductive success may lead to relatively low mortality during the second half of the active season. There was an overall trend toward lower mortality in 2year-old females than in older females, which supports this assumption. This is not surprising because 2-year-old females are still growing (Boag and Murie 1981; Dobson 1992) and successful reproduction might have a stronger effect on the mother's survival and future reproductive success than in full-grown females. However, Murie and Dobson (1987) found that there was a tendency towards a shorter life-span but higher lifetime reproductive success in females reproducing at a very young age in other populations of Columbian ground squirrels.

Lactating females exhibited lower survival than females who did not give birth. This difference continued through the lactation, postweaning, and hibernation periods. Females who were lactating but lost their litter before weaning had a better chance of surviving to the following spring than successfully reproducing females. This result suggests that the loss of the litter might increase chances of female survival, and could well be favored by natural selection, if low body condition or poor environmental situations (for example, weather; Neuhaus et al. 1999) lead to a high risk of mortality. A striking result was the better survivorship of females weaning young that survived to yearling age compared with females whose young did not reemerge the following spring. The reason for this might be that females in better condition not only survived better but also produced better offspring. Although "increasing returns" (Dobson et al. 1999) could explain this result, it could also be interpreted by the timing of the active season: offspring of late-breeding females have a lower chance of survival to yearling age, and mothers have less time to prepare properly for hibernation (Neuhaus 2000b), leading to higher mortality and less reproductive success. This is likely caused by early-reproducing females being heavier than late-breeding females (Neuhaus 2000b). Body condition has been shown to be an important factor in the 
Table 4. Percent survival of female Columbian ground squirrels to the next spring depending on their reproductive status and reproductive success.

\begin{tabular}{lllll}
\hline & $\begin{array}{l}\text { Percent } \\
\text { survival }\end{array}$ & Total & $\chi^{2}$ & $P$ \\
\hline Lactating & 75.7 & 230 & 11.47 & $<0.001$ \\
Not lactating & 83.5 & 115 & & \\
Weaned young & 79.1 & 148 & 11.73 & $<0.001$ \\
Lactated but no young weaned & 98.3 & 58 & & \\
Young survived to yearling age & 88.5 & 62 & 9.16 & 0.002 \\
Young did not survive to weaning age & 66.2 & 65 & & \\
\hline
\end{tabular}

Note: Females were chosen to be lactating or not when they disappeared for more than 24 days after mating. To test if weaning success had an influence on mortality, only females that lived at least to 51 days after mating were analyzed.

life history of Columbian ground squirrels, affecting reproductive success and survival (Murie and Boag 1984; Dobson and Kjelgaard 1985). Females therefore did not increase survival of their young by decreasing their own chance of survival, as is shown in the barn swallow, Hirundo rustica (Saino et al. 1999); rather the better recruitment of their offspring is positively correlated with their own survival when their body condition is good.

We expected that older females would bear a higher risk of mortality associated with reproduction than younger females. Only 2-year-olds showed reduced reproductive success, which could be interpreted as an investment into their own survival and future reproductive success. This could, however, also be caused by the fact that 2-year-old females are still growing, limiting their ability to reproduce successfully (Boag and Murie 1981; Dobson 1992). Survival of younger females, contrary to what we had expected, was not higher than the survival of older females, except for females $\geq 8$ years old. However, there was no reduction in reproductive success in older females, although one could speculate that the increase in mortality in older females, linked to a relatively high reproductive output, is caused by the high investment of females despite decreasing body condition due to senescence. Such speculations require further research.

While the literature shows that mortality is influenced by body condition (Dobson and Kjelgaard 1985), weather patterns, and year effects (Dobson and Murie 1987; Neuhaus et al. 1999), this study shows interactions between age, sex, reproductive status, and mortality. We conclude that mortality in male and female Columbian ground squirrels increases with age, likely owing to senescence and to costs associated with reproduction. Mortality of both sexes was low during hibernation and high during the active season, when reproduction takes place and predation is more likely. The reason for this seasonal difference might be that there are fewer factors that affect survival during hibernation than during the active season, when environmental influences are plentiful. Increased male mortality during the mating season shows that reproduction can be costly, for males especially, when environmental conditions are harsh (Neuhaus et al. 1999). Survival in females was lowest in successfully reproducing females and highest in females that did not give birth. Mortality in females can therefore be directly linked to their investment during lactation. The fact that mothers of young surviving to yearling age did survive better than mothers of young that did not survive to yearling age indicates that female body condition not only increased their reproductive success but also positively affected their own survival.

Observations of the Columbian ground squirrel population show that age and reproductive expenditure are important factors leading to mortality.

\section{Acknowledgements}

We thank the numerous field assistants without whose enthusiasm we would not have been able to do this work. The commission for travel grants of the Swiss Academy of Science and the Fonds pour la formation de chercheurs et aide à la recherche (Québec) and the Natural Sciences and Engineering Research Council of Canada supported the study. For constructive, critical comments on earlier drafts we thank F.S. Dobson, A. von Hardenberg, J.O. Murie, K.E. Ruckstuhl, and two anonymous reviewers. The University of Calgary Kananaskis field station provided space and facilities.

\section{References}

Atramenotowicz, M. 1992. Optimal litter size: does it cost more to raise a large litter in Caluromys philander? Can. J. Zool. 70: 1511-1515.

Bachman, G.C. 1993. The effect of body condition on the trade-off between vigilance and foraging in Belding's ground squirrels. Anim. Behav. 46: 233-244.

Barash, D.P. 1980. The influence of reproductive status on foraging by hoary marmots. Behav. Ecol. Sociobiol. 7: 201-205.

Bennett, R.B. 1997. Effects of variation on food quality on growth and survival of Columbian ground squirrels. M.S. thesis, University of Alberta, Edmonton.

Boag, D.A., and Murie, J.O. 1981. Weight in relation to sex, age, and season in Columbian ground squirrels (Sciuridae: Rodentia). Can. J. Zool. 59: 999-1004.

Clutton-Brock, T.H., Albon, S.D., and Guinness, F.E. 1989. Fitness costs of gestation and lactation in wild mammals. Nature (Lond.), 337: 260-262.

Dobson, F.S. 1992. Body mass, structural size, and life-history patterns of the Columbian ground squirrel. Am. Nat. 140: 109-125.

Dobson, F.S., and Kjelgaard, J.D. 1985. The influence of food resources on life history in Columbian ground squirrels. Can. J. Zool. 63: 2105-2109.

Dobson, F.S., and Murie, J.O. 1987. Interpretation of intraspecific life history patterns: evidence from Columbian ground squirrels. Am. Nat. 129: 382-397. 
Dobson, F.S., Badry, M.J., and Geddes, C. 1992. Seasonal activity and body mass of Columbian ground squirrels. Can. J. Zool. 70: 1364-1368.

Dobson, F.S., Risch, T.S., and Murie, J.O. 1999. Increasing returns in the life history of Columbian ground squirrels. J. Anim. Ecol. 68: $73-86$.

Festa-Bianchet, M., and King, W.J. 1984. Behavior and dispersal of yearling Columbian ground squirrels. Can. J. Zool. 62: 161-167.

Hare, J.F., and Murie, J.O. 1992. Manipulation of litter size reveals no cost of reproduction in Columbian ground squirrels. J. Mammal. 73: 449-454.

Hoogland, J.L. 1995. The black-tailed prairie dog: social life of a burrowing mammal. The University of Chicago Press, Chicago.

König, B., Riester, J., and Markl, H. 1988. Maternal care in house mice (Mus musculus): II. The energy cost of lactation as a function of litter size. J. Zool. (Lond.), 216: 195-210.

MacWhirter, R.B. 1991. Effects of reproduction on activity and foraging behaviour of adult female Columbian ground squirrels. Can. J. Zool. 69: 2209-2216.

Michener, G.R. 1984. Sexual differences in body weight patterns of Richardson's ground squirrels during the breeding season. J. Mammal. 65: 59-66.

Michener, G.R. 1998. Sexual differences in reproductive effort of Richardson's ground squirrels. J. Mammal. 79: 1-19.

Michener, G.R., and Locklear, L. 1990. Differential costs of reproductive effort for male and female Richardson's ground squirrels. Ecology, 71: 855-868.

Michener, G.R., and McLean, I.G. 1996. Reproductive behaviour and operational sex ratio in Richardson's ground squirrels. Anim. Behav. 52: 743-758.

Murie, J.O. 1995. Mating behavior of Columbian ground squirrels. 1. Multiple mating by females and multiple paternity. Can. J. Zool. 73: 1819-1826.

Murie, J.O., and Boag, D.A. 1984. The relationship of body weight to overwinter survival in Columbian ground squirrels. J. Mammal. 65: 688-690.

Murie, J.O., and Dobson, F.S. 1987. The costs of reproduction in female Columbian ground squirrels. Oecologia, 73: 1-6.

Murie, J.O., and Harris, M.A. 1978. Territoriality and dominance in male Columbian ground squirrels (Spermophilus columbianus). Can. J. Zool. 56: 2402-2412.
Murie, J.O., and Harris, M.A. 1982. Annual variation of offspring emergence and breeding in Columbian ground squirrels (Spermophilus columbianus). J. Mammal. 63: 431-439.

Neuhaus, P. 2000a. Weight comparisons and litter size manipulation in Columbian ground squirrels (Spermophilus columbianus) show evidence of costs of reproduction. Behav. Ecol. Sociobiol. 48: $75-83$.

Neuhaus, P. 2000b. Timing of hibernation and molt in female Columbian ground squirrels. J. Mammal. 81: 571-577.

Neuhaus, P., Bennett, R.B., and Hubbs, A. 1999. Effects of a late snowstorm and rain on survival and reproductive success in Columbian ground squirrels (Spermophilus columbianus). Can. J. Zool. 77: 879-884.

Norusis, M.J. 1994. SPSS graduate student statistical package. Version 6.1. SPSS Inc., Chicago.

Promislow, D.E.L. 1991. Senescence in natural populations of mammals: a comparative study. Evolution, 45: 1869-1887.

Saino, N.S., Calza, S., Ninni, P., and Møller, A.P. 1999. Barn swallows trade survival against offspring condition and immunocompetence. J. Anim. Ecol. 68: 999-1009.

Sherman, P.W., and Morton, M.L. 1984. Demography of Belding's ground squirrels. Ecology, 65: 1617-1628.

Sokal, R.R., and Rohlf, F.J. 1995. Biometry: the principles and practice of statistics in biological research. 3rd ed. W.H. Freeman and Co., New York.

Stearns, S.C. 1976. Life-history tactics: a review of the ideas. Q. Rev. Biol. 51: 3-47.

Stevens, S.D. 1997. High incidence of infanticide by lactating females in a population of Columbian ground squirrels (Spermophilus columbianus). Can. J. Zool. 76: 1183-1187.

Trivers, R.L. 1974. Parent-offspring conflict. Am. Zool. 14: 249-264.

Wiggett, D.R., and Boag, D.A. 1986. Establishing colonies of ground squirrels during active season. Wildl. Soc. Bull. 14: 288-291.

Wiggett, D.R., and Boag, D.A. 1993. The proximate cause of malebiased natal emigration in Columbian ground squirrels. Can. J. Zool. 71: 204-218.

Williams, G.C. 1966. Natural selection, the costs of reproduction, and a refinement of Lack's principle. Am. Nat. 100: 687-690.

Zammuto, R.M. 1987. Life histories of mammals: analyses among and within Spermophilus columbianus life tables. Ecology, 68: 1351-1363. 